\title{
Initial material for solving the main problems encountered in breeding winter rye in the northwestern zone of the USSR
}

\author{
V.D. KOBYLYANSKIJ \\ The N.I. Vavilov All-Union Scientific \\ Research Institute of Plant Industry \\ Herzen Str. 44 \\ 190000 Leningrad, USSR
}

\begin{abstract}
The main problems encountered in breeding winter rye in the northwestern region are: winterhardiness, lodging resistance, disease resistance and grain quality. Winterhardiness in the northwest of the USSR depends on the resistance of rye to snow mould. Varieties from the USSR (Vyatka, Falenskaja, Udinskaja, Narymskaja 23 and some others) and Austria (Lungauer Tauern, Schlager) as well as many varieties from Finland present valuable material for breeding for winterhardiness. The breeding of short-strawed varieties was promoted considerably by the use of donors with the dominant type of inheritance of the short straw characteristic (EM-1, k-10028) and many forms and varieties created on their basis. Nine commercial varieties with a high yield potential and winterhardiness were bred. Short-strawed donors resistant to powdery mildew and brown rust (Imering 4, Hetera 2, Immunnaja 5), unique in their kind and very valuable, were bred by introgression of the genes for resistance, which had been discovered in the populations of wild species and older varieties. A strategy of breeding rye for disease resistance is suggested. In breeding to improve grain quality, a gene bank of varieties, in which the stability of high grain quality is retained, is valuable. Some varieties have a protein content in the grain of $10 \%$, with a lysine content in the protein of $4 \%$ or more (Marienhofer, Wieselburger, Kisvardai). Four short-strawed analogues of commercial varieties (Ural'skaja HI, Tchishminskaja $\mathrm{Hl}$, Kustro $\mathrm{Hl}$, Stalrug $\mathrm{HI}$ ) are close to the variety Otello as to their baking qualities. The material presented on the inheritance of characteristics contributes to the selection of donors when new varieties are bred.
\end{abstract}

Index words: winter rye, winterhardiness, disease resistance, grain quality, donors

\section{Introduction}

During the last 10 years, certain progress has been observed in the breeding of winter rye in the USSR. Some varieties were bred that have improved winterhardiness and lodging resistance as compared to formed varieties. New commercial varieties, such as Voskhod 1, Voskhod 2, Chulpan, Saratovskaja 5, Yaroslavna, Kharkovskaja 12 and some 
others, have a yield potential up to $6-8 \mathrm{t} / \mathrm{ha}$. However, realization of the potential yield and of grain quality in many varieties is seldom attained in actual crop production, because of unsolved problems involving winterhardiness, lodging resistance, disease resistance and resistance to grain germination in the ear. These problems are of particular importance to rye breeding in northwestern regions of the European part of this country. The future task of breeders is to create varieties retaining high productivity under varying climatic conditions (Kobylyanskij 1982, Popov et al. 1986, SOLODUKHINA 1986).

With the object of solving different problems of breeding, the All-Union Scientific Research Institute disposes of the gene bank of specimens in the collection, in which nearly all the world's rye is presented. Improvement of the sources of the genes, which regulate characteristics useful to breeding programmes, contributes to the breeders' possibilities to improve varieties, bringing them closer to the ideal stipulated by the programme.

\section{Material and methods}

The gene of rye comprises: sources and donors with characteristics of high winterhardiness (frost resistance, snow mould resistance), lodging resistance (short-strawed donors and dwarf donors with a dominant and recessive genetic control), donors with disease resistance (powdery mildew, brown and stem rusts, snow mould), sources of the genes with high grain quality (high protein and lysine content, resistance of the grain to germination in the ear).

Modern methods of breeding are based on the use of multiple crossings which make it possible to combine a maximum of necessary characteristics and properties in one genotype. In many cases a cycle of crosses is carried out, using the method of convergent breeding and the method of recurrent or reciprocal crosses when $1-2$ valuable characteristics are required for improvement of the variety. The latter in combination with selection is very efficient in improving varieties as to the characteristics of winterhardiness, immunity to fungal disease, shortness of straw and grain quality.

When intraspecific and, particularly, interspecific hybridization is carried out, not only the combination of desired characteristics in plants is achieved, but also there arises the possibility of obtaining valuable transgressive characteristics absent from the varieties or species to be crossed. Selection from hybrid populations is then efficient when pair or mass cross-pollinations of plants are carried out, these having been singled out previously according to flowering under provocative conditions (KobylyANSKIJ 1982).

The most widely used method of breeding winter rye in the USSR is a manifold individual-strain selection and strain-group selection from cross-pollinated intervarietal hybrid populations known as the method of complicated populations (KRASNyuk 1946). During the last 10 years, creation of varieties, or synthetics, has been popular, and is based on combining strains with general combining ability (GCA), the effect of populational heterosis being used. When creating the synthetic variety Voskhod 2, GoncharenKo (1979) discovered heterosis in the strains with the best grain yield of $6.5-33.4 \%, 1000$ grain weight $-3.8 \%$, grain number in the ear $-3.1 \%$.

\section{Results and discussion}

Advances in the breeding of winter rye are universally determined by the rich genetic potential of the initial material, its suitability to the soil and climatic conditions of the zone of breeding, and knowledge of the principles governing the inheritance of characteristics used for breeding work.

In Europe, winterhardiness is determined by resistance to damping off, resulting from being affected by the snow mould pathogen, Fusarium nivale. In winter the low temperatures under the snow cover never reach the level dangerous to plant life. The search for 
initial material to use in breeding for resistance was conducted in climatic zones favourable to the development of the snow mould pathogen. Sources of resistance or tolerance to being affected by snow mould were discovered among rye species and varieties, the provenance of which are both mountain regions of the Caucasus and Asia and lowland northern regions of Europe and Asia.

In the populations of some varieties, 10$20 \%$ of the genotypes are immune to the effects of $F$. nivale under conditions of severe epiphytotics. These include varieties from Siberia - Udinskaja, Mnogokoloska, local rye k-7629, k-9612, k-3851, and from Austria - Lungauer Tauern, Schlager. Most of the locally bred varieties from Finland and northern regions of the USSR are noted for a high degree of tolerance to snow mould infection. With the object of creating resistant varieties, the following varieties may be recommended: from the USSR - Vyatka, Vyatka Severnaja, Falenskaja, Narymskaja 23, Kamalinskaja 13, Onika; local varieties from Austria - Lassaer, Kefermarkter; local varieties from the FRG - Otterbacher, Bergroggen; varieties from Finland - Onni, Ponsi, Ensi, Kelpo, Jussi. Of the wild species, the subspecies Kuprijanovii possesses the highest degree of resistance.

The dominance of resistance or tolerance characteristics to snow mould contributed to the use of backcross without interruption, the aim being to transfer resistance to modern winter rye varieties.

Specimens from the collection tolerant to snow mould infection were used in the breeding of new winter-hardy short-strawed varieties: Korotkostebel'naja 69, Korotkostebel'naja Tetra, Volkhova.

\section{Resistance to lodging}

A study of the gene bank of short-strawed winter rye varieties and specimens contributed to discovering the genetic differentiation of the short-straw characteristic, the independent genetic control and the linkage of every type of shortness of straw with productivity elements and grain yield. No correlation was discovered between the short-straw characteristic and winterhardiness in plants (KOBYLYANSKIJ 1982).

Of the four main short-strawed types, only two are well suited to creating the highest yielding varieties.

1. The polygenic recessive type of shortness of straw, with intermediate inheritance of the characteristic and influence of the protoplasm on the degree of its manifestation. The sources of this characteristic are the present West European varieties and some varieties from the USSR created on the basis of varieties from Petcus, GDR: Danae, Kustro, Kungs II, Dominant, Voskhod 1, Kombaininyaj, Tul'vi, Saratovskaja 5 and some others. This type of shortness of straw is widely and successfully used in rye breeding.

2. The monofactor dominant type of shortness of straw is controlled by the $\mathrm{Hl}$ gene (Dwarf 1). The donors of resistance are the natural mutant EM-1, single genotypes from local Bulgarian rye k-10028 and the specimen from Poland k-11. Because of the rather low yield ability of the above donors, breeding programmes use numerous winter rye forms and varieties with high yield, created on the basis of the mentioned donors.

The dominant shortness of straw characteristic was found not to be genetically linked with other characteristics reducing grain yield and decreasing the winterhardiness of plants. The pleiotropic effect of the gene regulating the short straw characteristic results in shorter internodes and straw up to $40 \%$, an increase in the bush habit of plants, in leaf and ear sizes, and in spikelets and grain in the ear. Independent genetic control of the characteristic contributes to combine the dominant shortstraw type with other types of recessive shortness of straw (KoBYLYANSKIJ 1975).

The dominant type of shortness of straw is used in rye breeding programmes by all the breeding institutions in the USSR. During a short period since 1979, nine short-strawed commercial varieties were created: Chulpan, 
Chulpan 3, Talovskaja 12, Khar'kovskaja 78, Orlovskaja 9, Kryzhachek, Verasen', Korotkosbel'naja 69, Tetra, Korotkaja. The last two are cultivated in western Siberia. In different climatic regions of the country, over $40 \%$ of the winter rye sowings are of the above varieties.

\section{Resistance to fungal diseases}

Intensification of the technology of winter rye cultivation made topical the problem of plant protection from harmful pathogens. The harmfulness of fungal diseases increased considerably when cultivating short-strawed varieties. In sowing the microclimate is made favourable to the development of all the pathogens, while shortening of the shorter stem increased the role of the leaves in the storage of the products of photosynthesis, which are necessary for grain yield formation. The situation arose in which similar infection of the leaves of long-strawed and shortstrawed plant varieties have a greater effect on the short-strawed varieties. In shortstrawed diploid rye, powdery mildew infection of $30-60 \%$ reduces grain yield by $28-$ $47 \%$. The same analogy is also observed with brown rust infection. Plant infection of 50$70 \%$ results in a $21-39 \%$ reduction of the yield, due to a decrease in the 1000 grain weight, the harmful action of the pathogen beginning with a damaged leaf area of $10 \%$. Reduction of the yield by more than $50 \%$ follows from stem rust and stem fusarial rot epiphytotics (SoloduKHINA 1986).

In all the world's winter rye varieties, there is no variety completely resistant to pathogens. The search for sources of resistance is carried out in populations of wild species and in old cultivated rye varieties. In populations of wild species, Secale montanum subspecies Kuprijanovii, collected in the region of the Caucasus, single genotypes immune to powdery mildew, brown leaf rust and stem rust were discovered. Single genotypes partly resistant to powdery mildew, brown rust and stem rust were found in old fodder and grain rye varie- ties: Grünschnitroggen (The GDR), Sangaste, Novozybkovskaja 4, Derzhavinskaja 29, Khar'kovskaja 60, and in some other related varieties. Based on the discovered sources of resistance, methods of selection and backcrosses give highly productive donors of these characteristics, the object being to use them in breeding programmes.

Resistance to powdery mildew, brown rust and stem rust was found to predominate over susceptibility in all the cases. In each individual case, resistance is controlled by one dominant gene - the Er and Pm 2 genes for powdery mildew, the $\mathrm{Pd}, \mathrm{Pd} 1$ genes for brown leaf rust. In our days donors were received combining both genes $(\mathrm{Er}, \mathrm{Pm} 2)$ for resistance to powdery mildew and shortness of straw - Imerig 4; donors combining shortness of straw and resistance to powdery mildew (Er, Pm 2) and to brown leaf rust (P) Hetera 2; those combining partial resistance to powdery mildew (Er) with resistance to brown rust $(\mathrm{Pd})$ and donors combining dominant shortness of straw $(\mathrm{Hl})$ and resistance to snow mould - Immunaja 5. If should be observed that, in all the cases, resistance to leaf rust has a race-specific heterogeneous nature; here, along with necrotic spots (supersensitivity reaction), differently developed pustules of the fungus are found.

Dominant genetic control of resistance to the pathogens determines the methods of selection when backcrosses without interruption and introgression of the genes for resistance in highly productive genotypes of rye are used. The selection of resistance in the genotypes in each backcross progeny should be carried out under artificial infected conditions previous to flowering of plants.

The strategy of breeding rye for resistance to diseases is based on differences in the genes for resistance, each type being resistant to a definite group of the pathogen races, and on the heterogeneity of varietal populations contributing to the long-term maintenance of resistance. In the breeding programme, four more probable directions may be included: 
- creation of varieties with one type of racespecific resistance;

- creation of polyresistant complicated populations obtained on the basis of combining plant varieties and strains with different types of race-specific resistance;

- creation of polyresistant varieties by introgression in their populations of the genes from different types of race-specific resistance;

- creation of varieties of polyresistant populations combining both race-specific and race non-specific resistance (KOBYLYANSKIJ and Solodukhina 1987).

Genetic control of resistance to diseases regulated by independent genes contributes to combining in one population not only different types of resistance to pathogen, but also resistance to various harmful diseases powdery mildew, leaf rust and stem rust, snow mould and some others.

\section{Grain quality}

The concept of grain quality in rye comprises the following main aspects: 1) food value (protein and essential amino acid content) and 2) technological properties (mainly baking qualities). The breeding of rye for an increased protein content in the grain advances poorly, as the problem associated with protein has been solved in many countries on account of other high-protein plants.
The gene bank of rye comprises a large diversity of varieties, forms, and species with respect to protein and essential amino acid content, particularly that of lysine. Among old and bred varieties, of special interest for breeding are the specimens with a $14 \%$ protein content in the grain and a more than $3 \%$ lysine content in protein: Manychskaja, Kamlinskaja 13, Sitnikovskaja (USSR); Mestnaja k-9514 (Yugoslavia); Balbo (USA); Explorer (Canada); Tisca Kozi Feher (Hungary); Gregerovo (Czechoslovakia). Still a higher protein content in the grain (over $17 \%$ ) and of lysine in protein (over $3 \%$ ) is discovered in single samples of weed rye, collected in regions of the Caucasus: k-5806, k-9633, $\mathrm{k}-10552$. Weed rye is easily crossed with cultivated rye, but is primitive as to other economically valuable characteristics - it is not lodging resistant, and gives poor yields.

The crossing of high protein varieties with low protein types gives intermediate inheritance of protein in the grain. Hybrids of a higher protein type (by $15 \%$ ) are obtained when the maternal components of the cross have a higher protein content.

With the object of breeding for the utmost high lysine content, initial material is discovered with a protein content in the grain of $10 \%$ and a lysine content in protein over $4 \%$ (Table 1).

Among the varieties with a high lysine content, specimens comprising high grain quali-

Table 1. Rye varieties high in lysine content.

\begin{tabular}{|c|c|c|c|c|c|}
\hline \multirow[t]{2}{*}{ Variety } & \multirow[t]{2}{*}{ Provenance } & \multirow{2}{*}{$\begin{array}{l}1000 \text { grain } \\
\text { weight } \mathrm{g}\end{array}$} & \multirow{2}{*}{$\begin{array}{c}\text { Protein } \% \\
(\mathrm{~N} \times 5.7)\end{array}$} & \multicolumn{2}{|c|}{ Lysine } \\
\hline & & & & $\begin{array}{c}\mathrm{gm} / 100 \\
\text { per } \mathrm{g} \\
\text { grain }\end{array}$ & $\begin{array}{l}\% \text { of } \\
\text { protein }\end{array}$ \\
\hline Marienhofer & Austria & 38.2 & 10.3 & 0.431 & 4.19 \\
\hline Wieselburger & $"$ & 41.4 & 10.2 & 0.427 & 4.20 \\
\hline Lungauer Tauern & $"$ & 31.5 & 10.1 & 0.410 & 4.07 \\
\hline Fleischmanns & Hungary & 31.0 & 10.9 & 0.464 & 4.27 \\
\hline Lovaszpatonai & $n$ & 36.0 & 11.3 & 0.464 & 4.11 \\
\hline Kisvardai & $"$ & 41.0 & 10.8 & 0.461 & 4.28 \\
\hline Nagucenki & $"$ & 35.7 & 10.6 & 0.437 & 4.13 \\
\hline Falenskaja & USSR & 28.6 & 10.0 & 0.423 & 4.23 \\
\hline Gibridnaja 2 & $"$ & 36.8 & 10.5 & 0.428 & 4.07 \\
\hline Volzhanka & $n$ & 31.3 & 11.1 & 0.446 & 4.03 \\
\hline
\end{tabular}


ty together with large grains, this being a positive fact for yield increase, have special value. Among high lysine content varieties, a particularly large grain (38.2-41.4 g) is found in Marienhofer, Wieselburger (Austria) and Kisvardai (Hungary).

The problems of improving the baking quality of rye may be solved by breeding work when varieties resistant to germination are involved in the hybridization. The Swedish variety Otello is very suitable for this purpose. Among local old rye varieties from the USSR (Yakutia, Kazakhstan), the samples k-10409 and k-8016 were found superior to the world standard Otello as to this characteristic.

In recent years, based on short-strawed analogues of rye varieties and forms, reliable sources of resistance to grain germination in the ear were created. EM-1, the donor of shortness of straw, possesses a high degree of resistance to germination, close to that of Otello. The value of the amylogram of EM-1 grain was noted to increase from $50 \mathrm{u}$.am. in 1976 to 430 u.am. in 1986, reproduction of the seeds having been carried out during 10 years under conditions of high air humidity (in the surroundings of Leningrad). In this connection, it is suggested that systematical year-to-year growing of short-strawed rye forms under conditions contributing to germination of the grain in the ear automatically results in the elimination from the population of the genotypes inclined to germination, and also results in the storage of the genotypes

\section{References}

Goncharenko, A.A Selekciya i semenovodstvo. 1979, No 1. 9-11.

KobylyanSKı, V.D. 1975. Rozh. Avtoreferat Dissertacii. L. 57 p.

- 1982. Rozh. Geneticheskiye osnovy selekcii. M.: 271 pp.

— \& Soloduknina, O.V. 1987. Strategiya selekcii rzhi na ustoichivost k boleznyam. Bull. VIR. No. 171.

Krasnyuk, A.A. 1946. Agrobiologiya, No. 2: 44-51.

Móller, H. \& Peters, C., 1979. Stand und Möglich-
Table 2. Short-strawed analogues of winter rye varieties best for grain quality.

\begin{tabular}{lccccc}
\hline Variety & \multicolumn{2}{c}{ Amylogram } & & \multicolumn{2}{c}{ Falling number } \\
\cline { 2 - 3 } & $\overline{\bar{x}}$ & range & & $\overline{\mathrm{x}}$ & range \\
\hline Otello & 325 & $225-430$ & & 275 & $201-346$ \\
Ural'skaja HI & 407 & $300-490$ & & 264 & $224-335$ \\
Chishminskaja HI & 300 & $240-370$ & & 226 & $170-291$ \\
Kustro & 373 & $290-520$ & & 234 & $193-261$ \\
Stalrug & 347 & $280-405$ & & 320 & $280-354$ \\
\hline
\end{tabular}

resistant to germination. In short-strawed sawings of rye, a higher air humidity is retained as compared to that in long-strawed ones, particularly in the sawings in the northwestern region of this country.

New sources of high baking quality are nonlodging short-strawed analogues of commercial varieties Ural'skaja $\mathrm{Hl}$, Chishminskaja 3 $\mathrm{Hl}$, Kustro $\mathrm{Hl}$, Stalrung $\mathrm{Hl}$, all of them being close to the variety Otello as to their technological properties (Table 2).

Hybrid analysis revealed a dominant digenic additive genetic control of the characteristic of low alpha-amylase activity in the grain, i.e. of resistance to germination (MúLLER and Peters 1979). The above determines the selection of the method to use for breeding rye for grain quality. The method comprises the use of the sources of resistance in backcross crosses along with individual strain selection of the plants to be backcrossed under provocative conditions. keiten der Entwicklung ertragreichter Roggensorten mit verbesserer Auswuchsfestigkeit in der DDR. - Archiv für Züchtungsforschung. H.5. B.9.

Popov, G.I., VAsko, V.T. \& PugaCh, N.G. Selekciya ozimoi rzhi. 1986. L.: 240.

Soloduknina, O.V. 1986. Sozdaniye donorov ustoichivosti $\mathrm{k}$ buroi rzhavchine i muchinistoi rose dlya selekcii diploidnoi rzhi. Avtoreferat dissertacii. Leningrad. $19 \mathrm{p}$. 


\section{SELOSTUS}

\section{Neuvostoliiton luoteisalueen syysrukiin- jalostuksen perusongelmien ratkaisemisen lähtöaineisto}

\section{V.D. Kobylyanskij}

The N.I. Vavilov All-Union Scientific

Research Institute of Plant Industry

Herzen Str. 44

190000 Leningrad, USSR

Luoteisen alueen rukiinjalostuksen pảäongelmat ovat talvenkeståvyys, lakoontumattomuus, taudinkeståvyys ja jyvăn laatu. Talvenkeståvyys on riippuvainen rukiin kestävyydestä lumihometta vastaan. Arvokasta aineistoa talvenkestävyysjalostusta varten tarjoavat neuvostoliittolaiset lajikkeet Vjatka, Falenskaja, Udinskaja, Narymskaja 23 ja eräăt muut, itävaltalaiset Lungauer Tauern ja Schlager samoinkuin monet suomalaiset rukiit.

Lyhytkortisen rukiin jalostus on edistynyt suuresti, kun risteytyksissä on ollut käytettävissä lyhytkortisuuden vallitsevana ominaisuutena sisăltăviä lähteitä, kuten EM-1 ja k-10028. On jalostettu yhdeksän kauppalajiketta, joilla on korkea sadontuottokyky ja hyvä talvenkestävyys. Lyhytkortiset hărmăn- ja ruskeanruosteenkeståvyyden lăh- teet Imering 4, Hetera 2 ja Immunaja 5 ovat erityisen arvokkaita. Ne on jalostettu siirtämällä villien lajien ja alkukantaisten rukiitten populaatioista kestävyyden tuottavia geenejä introgressioiden kautta. Artikkelissa esitetảän rukiin resistenssijalostuksen strategia.

Jyvăn laadun parantamisessa tarjoavat geenipankissa ylläpidetyt hyvăn jyvänlaadun omaavat lajikkeet arvokkaan perustan. Muutamien lajikkeiden, kuten Marienhofer, Wieselburger ja Kisvardai, valkuaispitoisuus on 10 prosenttia, lysiinipitoisuuden ollessa 4 prosenttia tai yli sen. Neljăn kauppalajikkeen, Ural'skaja Hl, Tchishminskaja Hl, Kustro Hl ja Stålruis HI, lyhytkortisuus-analogien leivontalaatu on lähellă Otello-lajikkeen tasoa. 